\title{
Selection for Profit in Cattle: II. Economic Weights for Dairy and Beef Sires in Crossbreeding Systems
}

\author{
M. Wolfová, ${ }^{* 1}$ J. Wolf, ${ }^{\star}$ J. Kvapilík, ${ }^{*}$ and J. Kica† \\ *Institute of Animal Science, PO Box 1, CZ 10401 Prague-Uhř́něves, Czech Republic \\ †Slovak Agriculture Research Center, Hlohovská 2, SK 94991 Nitra, Slovak Republic
}

\begin{abstract}
The relative economic importance (economic weights) of 18 traits was determined for Holstein and Charolais sires used in a dairy production system applying crossbreeding with beef sires and in a cow-calf pasture crossbreeding system with integrated fattening of surplus animals. A bioeconomic model containing a profit function was used for the calculations in both systems. Discounted expressions for direct and maternal components of the traits during an investment period of 25 yr were calculated using the gene-flow technique. The relative economic weights for some traits or trait components of the dairy sires differed substantially between the purebred and crossbred dairy systems. There were also meaningful differences among the relative economic weights of traits for beef sires, depending on whether these bulls were used for terminal crossing with $\mathrm{F}_{1}$ females in the cow-calf pasture system (backcrossing), for crossing in dairy herds producing slaughter animals, or for crossing in dairy herds producing $\mathrm{F}_{1}$ females for the cow-calf pasture system. We therefore recommend construction of specific sets of subindices for dairy and beef sires to allow users to rank the bulls according to expected merit of their progeny in specific production systems.
\end{abstract}

Key words: economic weight, crossing

\section{INTRODUCTION}

The expected removal of subsidies for slaughter cattle in the European Union will probably cause the costs of producing dairy bulls or heifers for slaughter to be higher than the revenues from selling these animals (Nielsen et al., 2004). Dairy farmers will therefore be motivated to produce beef of higher quality to obtain a higher price for carcasses. This can be achieved by a greater use of terminal crossbreeding with beef bulls in dairy herds.

Received September 20, 2006.

Accepted January 15, 2007.

${ }^{1}$ Corresponding author: wolfova.marie@vuzv.cz
Carcasses of purebred beef cattle or beef $\times$ dairy crossbreds are, in general, more valuable than carcasses of purebred dairy cattle. Davies et al. (1992) reported improved eating characteristics of meat when using crosses of a dairy breed with specialized beef breeds. Although fattening performance was similar, Güngör et al. (2003) reported a higher dressing percentage in beef $\times$ dairy crossbreds than in purebred dairy cattle. In Japan, a country with surplus milk production, Holstein cows with low production are crossed with the Japanese Black beef breed to produce $\mathrm{F}_{1}$ animals. This crossbreeding ensures that the cows in cow-calf production systems for beef can be replaced with low-cost $F_{1}$ females from the dairy herds (Kahi and Hirooka, 2006).

In the United Kingdom and Ireland, surplus crossbred beef $\times$ dairy heifers have often been used as replacements for cow-calf production systems by applying terminal crossing with beef bulls (Amer et al., 2001). But because of health problems and a reduction in the size of the dairy herd, application of this strategy has declined in the last decade (Roughsedge et al., 2003). Nevertheless, this production system is still attractive for dairy farmers in countries with less arable land for cropping and a higher proportion of pastures and meadows (e.g., in the Slovak Republic; Daňo et al., 2001). The advantage of using beef $\times$ dairy crossbred heifers for beef production is their higher milk yield potential, allowing faster growth of calves.

Wilton et al. (2002) showed that ranking Charolais sires for economic merit based on progeny results in a purebred population would be inaccurate if those same sires were used in certain crossbred production systems. Ranking of the sires was sensitive to the average performance in the population of cows to which they were bred. Amer et al. (2001) calculated a 3-fold higher economic value for calving ease for beef bulls mated to beef cows than for beef bulls mated to dairy cows. Differences in the ranking of dairy bulls could also be expected when using them in a purebred system or in systems with terminal crossing of dairy cows with beef bulls. 
Dairy farmers using terminal crossing on a portion of their herd might therefore be interested in having customized selection indices or subindices for ranking beef and dairy sires. Construction of such indices requires a special set of economic values calculated for different production systems and different selection groups of animals (Amer et al., 2001). Consequently, the aim of the present study was to calculate economic weights for traits of dairy and beef sires used in dairy herds and of beef sires used for terminal back-crossing with the crossbred beef $\times$ dairy cows. Holstein and Charolais, the most common dairy and beef breeds in the Czech Republic, were used for the calculations.

\section{MATERIALS AND METHODS}

\section{Description of the Production Systems}

A self-replacing Holstein dairy herd in a traditional indoor production system was simulated. In this system, $11 \%$ of the cows (the common proportion in the Czech Republic) were mated to Charolais bulls to produce progeny for beef production. All crossbred calves were reared together with dairy calves until 6 mo of age. Crossbred male calves were then fattened to a fixed slaughter weight. For female crossbred calves, 2 marketing strategies were examined: 1) fattening to a fixed slaughter weight (TCDH = terminal crossing in dairy herds) or 2) selling as breeding heifers $(\mathbf{S C B H}=$ selling crossbred breeding heifers) to an integrated cowcalf production system where they are terminally crossed to Charolais sires (producing back-cross progeny for slaughter). Dairy heifers were reared as herd replacements, and surplus pregnant heifers were sold at 7 mo of pregnancy. Consequently, in the dairy production system, some females were mated to produce replacement dairy heifers, whereas others were mated to produce animals for meat or for sale to another farm that produced terminal beef progeny.

The population structures in both the dairy herd and in the cow-calf pasture system were calculated as the stationary state of a Markov chain as described in previous papers (Wolfová et al., 2005a, 2007). Up to 10 reproduction cycles (intervals between 2 subsequent calvings or between calving and death or culling of cows) were assumed for the dairy system, whereas 15 reproduction cycles were allowed for the cow-calf pasture system. A detailed description of the management of both systems was published previously (Wolfová et al., 2005a, 2007).

Crossbred heifers for the cow-calf pasture system were purchased at 6 mo of age and mated at an average age of 15 mo. Natural mating with Charolais sires was performed beginning on May 1 and ending on June 29 (3 estrous cycles). Nonpregnant heifers were retained until the mating period in the following year. Those that did not conceive during that subsequent year were culled at an average of $60 \mathrm{~d}$ after the completion of matings. All nonpregnant cows and cows past their 15 th calving were slaughtered at the time of weaning of their current calf. Calves were weaned on October 15 and intensively fattened to a fixed slaughter weight. The pasture period for cows and heifers lasted from May 1 to October 30.

\section{Traits}

For dairy sires in the dairy system, the following 4 groups of traits were of interest for both marketing strategies.

Milk Production Traits. Milk yield for 305 d, fat percentage, and protein percentage were assigned to this group.

Growth Traits. Growth traits included birth weight, average daily gain for 4 periods (from birth to the end of the rearing period, from the end of the rearing period to first mating, from first mating to calving, and during the fattening period), and the mature weight of dairy cows.

Carcass Traits. Dressing percentage and average classes for fleshiness and fat covering based on the SEUROP carcass-grading system were used. In this grading system, there are 6 classes for fleshiness $(\mathrm{S}, \mathrm{E}$, $\mathrm{U}, \mathrm{R}, \mathrm{O}, \mathrm{P}$ ), where $\mathrm{S}$ is the best class and $\mathrm{P}$ is the worst class. To calculate the economic value for fleshiness, the numerical values 1 to 6 were inserted for $\mathrm{S}$ to $\mathrm{P}$. For fat covering, 5 classes ( 1 to 5 ) were distinguished.

Functional Traits. The traits belonging to this group were calving difficulty score, conception rate of heifers, conception rate of cows, calf mortality at birth, calf mortality during the rearing period, length of the productive life of cows, SCS, and incidence of clinical mastitis (CM) cases per cow per year. Calving difficulty score was expressed as the average class for calving difficulty ( 1 = easy calving without assistance, 2 = easy calving with assistance of 1 or 2 persons, $3=$ difficult calving with assistance of more than 2 persons or with veterinary assistance, and $4=$ cesarean section). Scores 3 and 4 constituted the definition of dystocia.

In the production system with the SCBH marketing strategy, the trait average daily gain of calves until weaning in the pasture system also was included for dairy sires. Except for the traits of milk production, length of productive life of cows, SCS, and CM, beef sires used in the dairy system were evaluated for the same traits as the dairy bulls. They also were evaluated for mature weight of the Charolais cows.

For beef sires used for terminal crosses in the cowcalf pasture system, the same carcass and functional traits as for dairy bulls, except for SCS and CM, were 
of interest. The growth traits, birth weight, pre- and postweaning daily gain, and mature weight of beef cows also were evaluated. For more detail on the definition of traits and on assumptions made about the impact of traits on revenues and costs, see Wolfová et al. (2005a) for beef traits and Wolfová et al. (2007) for dairy traits.

\section{Economic Efficiency of the Production Systems}

Profit (i.e., the difference between the present values of revenues and costs per cow and year at a stationary cow herd structure) was the criterion of economic efficiency for both modeled production systems. Revenues, costs, and profit were calculated as given in the accompanying paper (Wolfová et al., 2007).

Revenues in the dairy production system came from sales of milk, fattened bulls, pregnant dairy heifers, culled cows and heifers, and either fattened crossbred heifers (TCDH marketing strategy) or crossbred heifers for breeding (SCBH marketing strategy), and the value of manure. Revenues in the beef production system came only from sales of culled cows, fattened bulls, fattened heifers, and the value of manure.

Costs were calculated separately for feeding, housing, breeding, and health. All other costs (labor, interest on investments, energy, repairs, insurance, and overhead) were accounted for as fixed costs per animal for each category per day. Rations in the beef pasture system for cows, heifers, and calves until weaning were calculated separately for the summer and winter seasons. Feeding costs were then determined on the basis of daily net energy and protein requirements of animals and from the price for feed with given DM, net energy, and protein contents. The equations used for calculating net energy and protein requirements for beef and crossbred animals were taken from Fox et al. (1990), Vencl et al. (1991), AFCR (1993), Sommer et al. (1994), and Petrikovič and Sommer (2002).

Breeding costs in the dairy system were costs for AI and included the price for semen and labor. The price per insemination dose was $€ 17.86$ for Holstein bulls and $€ 7.14$ for Charolais bulls ( $€ 1=28$ Czech crowns). In the beef pasture system, breeding costs were calculated from the price of bulls for natural service lowered by the governmental subsidy for these bulls (€1,179/animal), and from the total costs for keeping these bulls in the herd for $6 \mathrm{yr}$, assuming an average bull-to-female ratio of 1:25. These costs were lowered by the sale value of culled bulls and recalculated per cow per year. The calculation of other cost components was described in detail in Wolfová et al. (2007).

\section{Calculation of Economic Weights for Direct and Maternal Effects of Traits}

As described in Wolfová et al. (2007), marginal economic values for each trait were calculated separately for each production system as the approximate partial derivative of the profit function with respect to that trait within that system. In general, economically important traits in cattle are of 2 types: 1) direct traits realized once in the life of an animal (e.g., mature weight, length of productive life) and 2) maternal traits realized repeatedly during the lifetime of dams (e.g., milk production). Several traits have both direct and maternal components (e.g., calving difficulty score, growth).

Although economic values are typically the same for direct and maternal effects of the same trait, the number and timing of their expression varies across different classes of selection candidates (Amer et al., 2001; Berry et al., 2006). The number of expressions of each trait expressed in the production systems following use of a dairy or beef bull will depend on the extent of crossbreeding in dairy herds, the marketing strategy for crossbred females (TCDH or SCBH), the age of the bulls in the selection group for which the number of expressions is to be calculated, and other factors (Wolfová and Nitter, 2004).

To account for different numbers of expressions for individual traits in distinct production systems (dairy system with marketing strategies TCDH or SCBH, the cow-calf pasture system), the numbers of discounted expressions for the 2 groups of traits or trait components (direct, maternal) and the 3 selection groups of interest (beef and dairy sires in the dairy production system and beef sires in the cow-calf pasture system) must be calculated. The gene-flow method developed by Hill (1974) and Elsen and Mocquot (1974) was applied for this calculation. The number of discounted expressions for trait group $j$ and selection group $k$ in production system $p\left(N D E_{j k p}\right)$ was calculated as follows:

$$
\begin{aligned}
& N D E_{j k p}=\mathbf{h}_{\mathbf{j}}^{\prime} \sum_{t=1}^{T} \mathbf{m}_{\mathbf{k}}[t](1+u)^{-t} \\
& \mathbf{m}_{\mathbf{k}}[t]=\mathbf{P}_{\mathbf{p}} \mathbf{m}_{\mathbf{k}}[t-1]=\ldots=\mathbf{P}_{\mathbf{p}}^{t} \mathbf{m}_{\mathbf{k}}[0],
\end{aligned}
$$

where $T$ is the investment period during which the gene expressions are summarized ( $25 \mathrm{yr}) ; \mathbf{m}_{\mathbf{k}}[t]$ is a column vector whose elements define the proportion of genes in each sex-age class at time $t$ that come from the original group $k$ of selected animals at time $0 ; \mathbf{P}_{\mathbf{p}}$ is the matrix of transition probabilities for production system $p$, which relates the proportion of genes in each sex-age class represented in $\mathbf{m}_{\mathbf{k}}[t-1]$ to the proportion of genes of the sex-age classes in $\mathbf{m}_{\mathbf{k}}[t] ; \mathbf{h}_{\mathbf{j}}^{\prime}$ is a row vector that describes the realization of trait group $j$; and $u$ is the 
discount rate per year (5\%). The age class was identical to the age in years.

The concrete forms of $\mathbf{h}_{\mathbf{j}}^{\prime}, \mathbf{m}_{\mathbf{k}}[t]$, and $\mathbf{P}_{\mathbf{p}}$ for the dairy production system in connection with the cow-calf pasture system were presented in Wolfová et al. (2005a). Nine age classes for dairy sires and 6 age classes for beef sires were assumed in the dairy system. In the cow-calf production system, 7 age classes for beef sires were assumed. The numbers of discounted expressions were calculated for 2-yr-old dairy and beef bulls.

Within both groups of traits (direct and maternal), the numbers of discounted expressions were equal for all traits because the marginal economic values of all traits were already expressed per cow and year and were discounted to the time of calving (Wolfová et al., 2007). That is, they already included the first generation of progeny.

The economic weight $\left(e w_{l j k p}\right)$ for trait $l$ within the $j$ th group of traits, for selection group $k$, and for production system $p$ (a dairy production system with the TCDH marketing strategy or a cow-calf production system) was calculated as

$$
e w_{l j k p}=e v_{l p} N D E_{j k p},
$$

where $e v_{l p}$ is the marginal economic value of trait $l$.

In the dairy production system that supplies crossbred replacement females for the cow-calf pasture system (SCBH marketing strategy), a somewhat different approach must be used to calculate economic weights, because the economic value for a given trait is different when expressed in crossbred progeny of the dairy system or in crossbred progeny of the beef pasture system. Therefore, the realization vectors $\mathbf{h}_{\mathbf{j}}^{\prime}$ from equation [1] have to be multiplied first by the vectors of economic values for traits expressed in the different progeny groups. Equation [2] will then have the following form:

$$
e w_{l j k p}=\mathbf{h}_{\mathbf{j}}^{\prime} \circ \mathbf{e v}_{\mathbf{l j p}}^{\prime} \sum_{t=1}^{T} \mathbf{m}_{\mathbf{k}}[t](1+u)^{-t},
$$

where $\mathbf{e v}_{\text {lip }}^{\prime}$ is the joint vector of economic values for trait $l$ and trait group $j$ in the joined dairy and beef pasture system. The operator $\bigcirc$ stands for the elementwise product of vectors. The form of the vector $\mathbf{e v}_{\mathbf{l j p}}^{\prime}$ can be found in Wolfová et al. (2005a).

For a better comparison of the relative importance of different traits between production systems, marketing strategies, and breeds, relative standardized economic values for direct and maternal traits or trait components were calculated as follows:

$$
e w r_{l j k p}=100 e w_{l j k p} s_{l j} /\left|e w_{c 1 k p} s_{c 1}\right|
$$

where $e w r_{l j k p}$ is the relative standardized economic weight for the $j$ th component $(j=1$ : direct effect; or $j=$ 2 : maternal effect) of trait $l$ in production system $p$ and selection group $k$ (dairy or beef sires in a dairy system, beef sires in a cow-calf pasture system), $s_{l j}$ is the genetic standard deviation for the $j$ th component of trait $l$, and subscript $c$ refers to the calving difficulty score for beef sires or 305-d milk for dairy sires. Using this approach, the standardized economic weights were expressed as percentages of the absolute value of the standardized economic weight for the direct component of calving difficulty score or milk yield. If no values were available separately for the genetic standard deviations of direct and maternal components of traits, the same values were used for both components.

\section{Input Parameters}

The input parameters for the dairy system as well as beef and feed prices for the beef pasture system were the same as those used by Wolfová et al. (2007) for scenario 2 (expected situation in year 2015). However, the voluntary culling rate in dairy cow herds with terminal crossing was set much lower than those in herds with purebreeding to produce enough purebred heifers for replacement. The corresponding culling rates for low milk production were 5\% in the first lactation, $10 \%$ in the second, and none in subsequent lactations. The consequence of reduced selection emphasis on milk yield was lower milk production of the herd, which was set to $7,400 \mathrm{~kg}$ instead of $8,000 \mathrm{~kg} / \mathrm{cow}$ per $\mathrm{yr}$ in the purebred Holstein herd, but with slightly higher fat and protein percentages (3.85 and 3.26\%, respectively).

The health and reproduction parameters assumed for the pasture beef system are given in Table 1. Crossbred Charolais $\times$ Holstein cows were expected to have higher milk production than purebred Charolais cows (peak milk yield on pasture, $12 \mathrm{~kg} / \mathrm{d}$ instead of $8 \mathrm{~kg} / \mathrm{d}$ ). The mature weight of Charolais bulls was $1,000 \mathrm{~kg}$, and their length of productive life in natural mating was $6 \mathrm{yr}$.

Progeny performance in the dairy and pasture systems is shown in Table 2. Three genotypes of progeny were distinguished: purebred Holstein $(\mathrm{H})$, Charolais $\times$ Holstein crosses $(\mathrm{CH} \times \mathrm{H})$, and Charolais $\times($ Charolais $\times$ Holstein) backcrosses $[\mathrm{CH} \times(\mathrm{CH} \times \mathrm{H})]$. Animal mortality during fattening was $1 \%$ in all progeny groups. Five percent of animals were slaughtered before reaching the target slaughter weight because of health problems. Dressing percentages and carcass prices for these animals were lowered by $20 \%$. Differences in carcass quality among the genotypes can be seen in Table 3, which gives the proportion of bull and heifer carcasses in the individual fleshiness and fat covering classes 
Table 1. Health and reproductive parameters for the pasture beef system

\begin{tabular}{lc}
\hline Parameter & Value \\
\hline Mortality rate of cows per reproduction cycle 1, \% & 2 \\
Mortality rate of cows per reproduction cycles $\geq 2, \%$ & 1 \\
Culling rate due to health problems other than dystocia in cycle 1, \% & 2 \\
Culling rate due to health problems other than dystocia in cycles $\geq 2, \%$ & 5 \\
Culling rate after dystocia, \% & 10 \\
Dystocia rate ${ }^{1}$ for female calves in reproduction cycle 1, \% & 4.3 \\
Dystocia rate for female calves in reproduction cycles $\geq 2, \%$ & 2.2 \\
Dystocia rate for male calves in reproduction cycle 1, \% & 9.0 \\
Dystocia rate for male calves in reproduction cycles $\geq 2, \%$ & 4.4 \\
Abortion rate, mean for all cycles, in \% & 1 \\
Stillbirth rate for cows having easy calving in reproduction cycle 1, \% & 2 \\
Stillbirth rate for cows having easy calving in reproduction cycles $\geq 2, \%$ & 1 \\
Calves dying within $48 \mathrm{~h}^{3}$ after easy calving in reproduction cycle 1, \% & 0.6 \\
Calves dying within $48 \mathrm{~h}$ after easy calving in reproduction cycles $\geq 2, \%$ & 0.5 \\
Calves dying within $48 \mathrm{~h}^{3}$ after dystocia for all reproduction cycles, \% & 50 \\
Conception rate of females at the first estrus, \% & 60 \\
Conception rate of females at the second estrus, \% & 70 \\
Conception rate of females at the third estrus, \% & 50 \\
\hline
\end{tabular}

${ }^{1}$ Sum of calving difficulty scores 3 and 4 , on a scale of 1 (easy) to 4 (cesarian section).

${ }^{2}$ Sum of calving difficulty scores 1 and 2 , on a scale of 1 (easy) to 4 (cesarian section).

${ }^{3}$ As a proportion of calves born alive.

according to the SEUROP grading system. Price differences among the classes were those given in the companion paper (Wolfová et al., 2007). Input parameters for calculating costs in the cow-calf pasture system are listed in Table 4.

\section{RESULTS}

Cow herd structures modeled by Markov chains and the resulting distributions of progeny for the dairy and cow-calf pasture production systems are given in Table 5 . The length of productive life, expressed as the number of calvings, was 3.67 for Holstein cows and 7.14 for Charolais $\times$ Holstein cows.

Economic efficiency (and its components) for the 2 marketing strategies for progeny (TCDH and SCBH) of the dairy production system and of the cow-calf pasture system are shown in Table 6. In the dairy system, similar economic efficiency (profitability of approximately $-3.8 \%$ ) was achieved from both marketing strategies,

Table 2. Progeny performance by production system and genotype of progeny

\begin{tabular}{|c|c|c|c|}
\hline \multirow[b]{2}{*}{ Trait } & \multicolumn{3}{|c|}{ Progeny group ${ }^{1}$ (production system) } \\
\hline & $\begin{array}{c}\mathrm{H} \\
\left(\text { dairy }^{2}\right)\end{array}$ & $\begin{array}{c}\mathrm{CH} \times \mathrm{H} \\
\text { (dairy) }\end{array}$ & $\underset{\left(\text { cow-calf }{ }^{3}\right)}{\mathrm{CH} \times(\mathrm{CH} \times \mathrm{H})}$ \\
\hline Birth weight of female calves, $\mathrm{kg}$ & 35 & 36 & 37 \\
\hline Birth weight of male calves, $\mathrm{kg}$ & 38 & 39 & 40 \\
\hline Weight of females at $210 \mathrm{~d}$ of age, $\mathrm{kg}$ & & & 246 \\
\hline Weight of males at $210 \mathrm{~d}$ of age, $\mathrm{kg}$ & & & 264 \\
\hline Weight of females at $365 \mathrm{~d}$ of age, $\mathrm{kg}$ & & & 336 \\
\hline Weight of males at $365 \mathrm{~d}$ of age, $\mathrm{kg}$ & & & 424 \\
\hline Mature weight of cows, $\mathrm{kg}$ & 640 & 700 & \\
\hline Daily gain of female calves in rearing, $\mathrm{kg} / \mathrm{d}$ & 0.80 & 0.9 & \\
\hline Daily gain of male calves in rearing, $\mathrm{kg} / \mathrm{d}$ & 0.90 & 1.00 & \\
\hline Daily gain of heifers in fattening, $\mathrm{kg} / \mathrm{d}$ & 0.80 & 1.05 & 1.20 \\
\hline Daily gain of bulls in fattening, $\mathrm{kg} / \mathrm{d}$ & 1.10 & 1.30 & 1.30 \\
\hline Slaughter weight of fattened heifers, $\mathrm{kg}$ & 450 & 525 & 550 \\
\hline Slaughter weight of fattened bulls, $\mathrm{kg}$ & 600 & 650 & 680 \\
\hline Dressing percentage of heifers, $\%$ & 52.0 & 57.5 & 58.0 \\
\hline Dressing percentage of bulls, $\%$ & 55.0 & 60.0 & 60.0 \\
\hline Dressing percentage of cows, $\%$ & 50.0 & 55.0 & \\
\hline
\end{tabular}

${ }^{1}$ Progeny groups: $\mathrm{H}=$ Holstein; $\mathrm{CH}=$ Charolais.

${ }^{2}$ Indoor dairy system with purebred Holstein cows applying partly terminal crossing with Charolais sires.

${ }^{3}$ Cow-calf pasture system with crossbred cows (Charolais $\times$ Holstein) applying terminal crossing with Charolais sires. 
Table 3. Percentage of bull and heifer carcasses in commercial classes for fleshiness ${ }^{1}$ and fat covering ${ }^{2}$

\begin{tabular}{|c|c|c|c|c|c|}
\hline \multirow{2}{*}{$\begin{array}{l}\text { Fleshiness } \\
\text { classes }\end{array}$} & \multicolumn{5}{|c|}{ Fat covering classes } \\
\hline & 1 & 2 & 3 & 4 & 5 \\
\hline \multicolumn{6}{|l|}{ Bulls } \\
\hline \multirow[t]{3}{*}{$\mathrm{E}(2)$} & 0 & 0 & 0 & 0 & 0 \\
\hline & 0 & 4.6 & 2.6 & 0.8 & 0 \\
\hline & 0.3 & 2.0 & 1.4 & 0.4 & 0.2 \\
\hline \multirow[t]{3}{*}{$\mathrm{U}(3)$} & 0 & 0.8 & 0.7 & 0 & 0 \\
\hline & 0 & 17.0 & 9.6 & 3.0 & 0 \\
\hline & 4.5 & 25.0 & 18.0 & 6.0 & 1.2 \\
\hline \multirow[t]{3}{*}{$\mathrm{R}(4)$} & 0 & 6.4 & 5.0 & 0 & 0 \\
\hline & 0 & 16.0 & 8.2 & 3.0 & 0 \\
\hline & 3.0 & 18.0 & 11.0 & 5.0 & 1.0 \\
\hline \multirow[t]{3}{*}{$\mathrm{O}(5)$} & 0.3 & 42.8 & 31.2 & 0.3 & 0 \\
\hline & 0 & 15.4 & 9.6 & 3.8 & 0 \\
\hline & 0.2 & 1.0 & 0.8 & 0.5 & 0.5 \\
\hline \multirow[t]{3}{*}{$\mathrm{P}(6)$} & 0.7 & 8.5 & 3.3 & 0 & 0 \\
\hline & 0 & 4.0 & 2.0 & 0 & 0 \\
\hline & 0 & 0 & 0 & 0 & 0 \\
\hline \multicolumn{6}{|l|}{ Heifers } \\
\hline \multirow[t]{3}{*}{$\mathrm{E}(2)$} & 0 & 0 & 0 & 0 & 0 \\
\hline & 0 & 0 & 0 & 0 & 0 \\
\hline & 0 & 0.4 & 1.0 & 0.5 & 0.1 \\
\hline \multirow[t]{3}{*}{$\mathrm{U}(3)$} & 0 & 0 & 0 & 0.3 & 0.2 \\
\hline & 0.1 & 0.6 & 0.5 & 0.5 & 0.3 \\
\hline & 0 & 2.2 & 10.0 & 4.0 & 1.0 \\
\hline \multirow[t]{3}{*}{$\mathrm{R}(4)$} & 0 & 1.2 & 2.6 & 2.2 & 0.2 \\
\hline & 0.6 & 6.4 & 4.6 & 5.0 & 3.4 \\
\hline & 0 & 8.0 & 43.0 & 16.5 & 5.0 \\
\hline \multirow[t]{3}{*}{$\mathrm{O}(5)$} & 0.2 & 16.0 & 35.0 & 20.2 & 4.6 \\
\hline & 2.1 & 22.4 & 16.1 & 17.5 & 11.9 \\
\hline & 0 & 1.0 & 4.1 & 2.0 & 1.2 \\
\hline \multirow[t]{3}{*}{$\mathrm{P}(6)$} & 0.5 & 6.4 & 7.0 & 2.7 & 0.7 \\
\hline & 0.2 & 2.6 & 1.8 & 2.0 & 1.4 \\
\hline & 0 & 0 & 0 & 0 & 0 \\
\hline
\end{tabular}

${ }^{1}$ Where $\mathrm{S}$ is the best class and $\mathrm{P}$ is the worst class. Fleshiness class $\mathrm{S}$ (1) is omitted from the table because the proportion of carcasses in this class was always zero.

${ }^{2}$ From top to bottom, the first number is for purebred Holstein $(\mathrm{H})$ animals, the second is for Charolais $\times$ Holstein $(\mathrm{CH} \times \mathrm{H})$ crosses, and the third is for $\mathrm{CH} \times(\mathrm{CH} \times \mathrm{H})$ backcrosses. whereas profitability of the cow-calf pasture system was considerably less $(-15.6 \%)$. Under the assumed conditions, therefore, all production systems would operate at a loss. It must be noted, however, that neither direct payment from the European Union nor governmental subsidies were included in these economic results. In practice, such external support may exceed projected losses for both dairy and beef farms.

Marginal economic values for all evaluated traits are shown in Tables 7 to 9. The negative economic values for SCS, CM incidence, calving difficulty score, losses of calves, and fleshiness were caused by the fact that any increase in these traits as defined would result in a decrease in profit. Fat covering has a price optimum in fat class 3 within the $\mathrm{O}$ and $\mathrm{P}$ classes of the SEUROP fleshiness grading. The economic value for this trait may therefore be positive or negative, according to the prior distribution of carcasses among fat covering classes. The birth weight of calves and the mature weight of cows had negative economic values, because larger animals would have higher feed costs to maintain BW. The negative economic value for conception rate of cows in the cow-calf pasture system showed that the assumed starting value for this trait was above its optimum for the given economic circumstances.

The relative economic weights of traits and trait components (direct and maternal) calculated according to equation [4] are summarized in Table 10 for Holstein sires. In addition to the 2 marketing strategies in the dairy system with crossing, a purebred dairy system was considered. For this purpose, relative economic weights were calculated on the basis of the results for scenario 2 in the companion paper (Wolfová et al., 2007), which assumed no market quotas for milk or milk components.

Table 4. Input parameters used to calculate costs in the cow-calf pasture production system

\begin{tabular}{lr}
\hline Parameter & Value $^{1}$ \\
\hline Costs for veterinary treatment & 14.29 \\
Cows with calves until weaning, €/yr and cow & 14.29 \\
Heifers from weaning to calving, €/animal & 7.14 \\
Breeding bulls for natural mating, €/animal & 7.14 \\
Animals in fattening, €/animal & 0.43 \\
Fixed costs, €/d and animal & 0.36 \\
Cows with calves until weaning & 0.36 \\
Heifers from weaning to calving & 0.43 \\
Breeding bulls for natural mating & 30.00 \\
Animals in fattening & 74.25 \\
Veterinary costs connected with calving score 3, €/calving & 14.29 \\
Veterinary costs connected with calving score 4, €/calving & 7.14 \\
Cost for removing and rendering a dead cow, €/animal & $1,178.57$ \\
Cost for removing and rendering a dead young animal, €/animal & 0.54 \\
Price per Charolais breeding bull for natural mating, €/animal & 0.07 \\
Price of straw for housing, €/100 kg &
\end{tabular}

${ }^{1} € 1=28$ Czech crowns. 
Table 5. Modeled herd structure for the dairy and cow-calf pasture systems ${ }^{1}$

\begin{tabular}{lcc}
\hline Variable & $\begin{array}{c}\text { Dairy } \\
\text { system }^{2}\end{array}$ & $\begin{array}{c}\text { Cow-calf } \\
\text { system }\end{array}$ \\
\hline Number of cows in a reproduction cycle & & 14.01 \\
1 & & 12.49 \\
2 & 27.27 & 10.97 \\
3 & 18.96 & 9.64 \\
4 & 12.83 & 8.48 \\
5 & 9.95 & 7.45 \\
6 & 7.89 & 6.55 \\
7 & 6.51 & 5.75 \\
8 & 5.37 & 5.05 \\
9 & 4.44 & 4.43 \\
10 & 3.67 & 3.88 \\
11 & 3.11 & 3.40 \\
12 & - & 2.98 \\
13 & - & 2.62 \\
14 & - & 2.30 \\
15 & - & \\
Progeny & - & 94.20 \\
Number of calves born alive & & 87.30 \\
Number of calves reared & $85.08(10.62)$ & 40.78 \\
Number of bulls fattened to target slaughter weight & $77.95(9.79)$ & 41.24 \\
Number of dairy heifers reared for replacement & $35.86(4.51)$ & - \\
Number of dairy heifers sold pregnant & $(4.55)$ & - \\
Number of crossbred heifers sold to cow-calf pasture systems ${ }^{5}$ & 33.97 & - \\
\hline
\end{tabular}

\footnotetext{
${ }^{1}$ All numbers are given per 100 cows per year.

${ }^{2}$ The numbers of progeny are given for purebred Holstein and, in parentheses, for crossbred Charolais $\times$ Holstein progeny.

${ }^{3}$ Reproduction cycle means the interval between 2 subsequent calvings.

${ }^{4}$ Only in marketing strategy TCDH (terminal crossing in dairy herds: all crossbred calves and dairy calves not needed for replacement are fattened).

${ }^{5}$ Only in marketing strategy SCBH (selling crossbred breeding heifers: all male crossbred calves and dairy calves not needed for replacement are fattened; female crossbred calves are sold to the integrated cow-calf pasture system).
}

Although the most important trait was milk yield followed by SCS in the purebred system, the maternal component of conception rate of cows and CM incidence were more important than milk yield in the crossbreeding system with both marketing strategies. The mater-

Table 6. Economic results of the dairy production systems with marketing strategies $\mathrm{TCDH}^{1}$ and $\mathrm{SCBH}^{2}$ and for the cow-calf pasture system with terminal crossing (in €/cow and year, without subsidies)

\begin{tabular}{|c|c|c|c|}
\hline \multirow{2}{*}{$\begin{array}{l}\text { Economic } \\
\text { characteristic }\end{array}$} & \multicolumn{2}{|c|}{$\begin{array}{c}\text { Dairy system } \\
\text { with marketing strategy }\end{array}$} & \multirow{2}{*}{$\begin{array}{l}\text { Cow-calf } \\
\text { pasture } \\
\text { system }\end{array}$} \\
\hline & $\mathrm{TCDH}$ & $\mathrm{SCBH}$ & \\
\hline Total revenues & 1,988 & 1,976 & 851 \\
\hline Total costs & 2,067 & 2,051 & 1,008 \\
\hline Profit & -80 & -75 & -157 \\
\hline Profitability, ${ }^{3} \%$ & -3.8 & -3.7 & -15.6 \\
\hline
\end{tabular}

${ }^{1}$ Terminal crossing in dairy herds: all crossbred calves and dairy calves not needed for replacement are fattened.

${ }^{2}$ Selling crossbred breeding heifers: all male crossbred calves and dairy calves not needed for replacement are fattened; female crossbred calves are sold to the integrated cow-calf pasture system.

${ }^{3}$ Calculated as $100 \times$ profit/total costs. nal component of calf mortality at birth, milk yield, and SCS were the next most important traits for dairy sires in the dairy system with crossing. For dairy sires in all 3 systems, these traits were followed by the milk components, reaching 27 to $49 \%$ of the importance of milk yield, and by the length of productive life of cows, reaching 37 to $44 \%$ of the importance of milk yield. The direct and maternal components of birth weight and the mean fat covering class were among the least important

Table 7. Marginal economic values (in €/cow, year, and unit of the trait) for traits specific to the dairy system

\begin{tabular}{lc}
\hline Trait & $\begin{array}{c}\text { Economic } \\
\text { value }^{1}\end{array}$ \\
\hline 305-d milk yield, ${ }^{2} \mathrm{~kg}$ & 0.106 \\
Milk fat percentage, \% & 75.14 \\
Milk protein percentage, \% & 253.43 \\
SCS & -317.43 \\
Clinical mastitis incidence, cases/cow-year & -59.78 \\
\hline
\end{tabular}

${ }^{1}$ The economic values are equal for both marketing strategies.

${ }^{2}$ Milk with fixed (average) fat and protein percentages. 
Table 8. Marginal economic values (in €/cow, year, and unit of the trait) for traits realized in the dairy progeny

\begin{tabular}{lrr}
\hline & \multicolumn{2}{c}{$\begin{array}{c}\text { Economic value for } \\
\text { marketing strategy }\end{array}$} \\
\cline { 2 - 3 } Trait & $\mathrm{TCDH}^{1}$ & $\mathrm{SCBH}^{2}$ \\
\hline Calving difficulty score & -108.9 & -111.2 \\
Calf mortality at birth, \% & -0.77 & -0.96 \\
Calf mortality during the rearing period, \% & -1.85 & -2.11 \\
Conception rate of heifers, \% & 0.75 & 0.75 \\
Conception rate of cows, \% & 4.25 & 4.29 \\
Length of productive life of cows, yr & 59.82 & 60.36 \\
Birth weight, kg & -0.10 & -0.12 \\
Mature weight of cows, kg & -0.46 & -0.41 \\
Daily gain in the rearing period, g/d & 0.14 & 0.14 \\
Daily gain in fattening, g/d & 0.17 & 0.15 \\
Dressing percentage, \% & 7.89 & 7.89 \\
Fleshiness class & -53.07 & -53.07 \\
Fat covering class & 1.97 & 1.97 \\
\hline
\end{tabular}

${ }^{1}$ Terminal crossing in dairy herds: all crossbred calves and dairy calves not needed for replacement are fattened.

${ }^{2}$ Selling crossbred breeding heifers: all male crossbred calves and dairy calves not needed for replacement are fattened; female crossbred calves are sold to the integrated cow-calf pasture system.

traits in all systems (values near zero). An increase in birth weight caused a shortening of the fattening period of bulls and in the rearing period of heifers, but resultant monetary savings were canceled by increasing feed costs for maintenance of heavier animals. The low relative importance of carcass traits was caused by low price differences among the fleshiness and fat covering classes (see Wolfová et al., 2007).

When comparing the sets of economic weights for dairy sires for the TCDH and SCBH marketing strategies, the relative importance of the reproduction traits in strategy SCBH was slightly higher, but the differences were very small. Therefore, the weighting of these traits in the breeding objective for dairy sires could be the same for both marketing strategies.

The relative economic weights for Charolais sires in the dairy system with both marketing strategies and in the cow-calf system are shown in Table 11. Weights in the dairy system differed substantially between marketing strategies. When applying terminal crossing in the dairy system, maternal components of traits were never expressed in the progeny of beef sires, whereas maternal components could be important in crossbred breeding females (the maternal component of calf losses at calving, for example).

The direct component for cow conception rate was the most important trait for beef sires in the dairy systems, whereas the direct component of calf mortality at birth reached one-third to one-half the value of the economic weight for cow conception rate. Daily gain during fattening, dressing percentage, and calving difficulty score followed, in order of importance.

For beef sires used for terminal backcrossing in the cow-calf pasture system, only the direct component of each trait was expressed. The most important traits for beef sires in this system were calving difficulty score, dressing percentage, and daily gain during fattening, followed by calf mortality at birth. None of the remaining traits reached more than $6 \%$ of the economic importance of calving difficulty score. As was true for dairy sires, the birth weight of calves and carcass traits were lowest in economic importance for beef sires.

Table 9. Marginal economic values (in €/cow, year, and unit of the trait) for traits realized in the crossbred progeny

\begin{tabular}{|c|c|c|c|}
\hline \multirow[b]{2}{*}{ Trait } & \multicolumn{2}{|c|}{$\begin{array}{l}\text { Dairy system with } \\
\text { marketing strategy }\end{array}$} & \multirow{2}{*}{$\begin{array}{l}\text { Cow-calf } \\
\text { production } \\
\text { system }\end{array}$} \\
\hline & $\mathrm{TCDH}^{1}$ & $\mathrm{SCBH}^{2}$ & \\
\hline Calving difficulty score & -15.43 & -15.82 & -38.64 \\
\hline Calf mortality at birth, $\%$ & -1.00 & -1.40 & -3.36 \\
\hline Calf mortality during the rearing period or until weaning, \% & -0.25 & -0.30 & -3.59 \\
\hline Conception rate of heifers, $\%$ & - & - & 0.50 \\
\hline Conception rate of cows, $\%$ & 4.25 & - & -0.31 \\
\hline Length of productive life of cows, yr & - & - & 4.54 \\
\hline Birth weight, kg & 0.05 & 0.08 & -0.32 \\
\hline Mature weight of cows, $\mathrm{kg}$ & -0.004 & 0.0005 & -0.0274 \\
\hline Daily gain during the rearing period or until weaning, $g / d$ & 0.003 & 0.010 & -0.105 \\
\hline Daily gain during fattening, $\mathrm{g} / \mathrm{d}$ & 0.029 & 0.015 & 0.187 \\
\hline Dressing percentage, $\%$ & 1.20 & 0.73 & 13.11 \\
\hline Fleshiness class & -5.75 & -3.03 & -47.71 \\
\hline Fat covering class & -2.99 & -1.56 & -35.18 \\
\hline
\end{tabular}

${ }^{1}$ Terminal crossing in dairy herds: all crossbred calves and dairy calves not needed for replacement are fattened.

${ }^{2}$ Selling crossbred breeding heifers: all male crossbred calves and dairy calves not needed for replacement are fattened; female crossbred calves are sold to the integrated cow-calf pasture system. 
Table 10. Relative standardized economic weights ${ }^{1}$ for Holstein sires used in a purebred dairy system or in dairy production systems realizing crossbreeding with beef bulls

\begin{tabular}{|c|c|c|c|}
\hline \multirow[b]{2}{*}{ Trait } & \multirow{2}{*}{$\begin{array}{l}\text { Purebred }^{2} \\
\text { dairy } \\
\text { system }\end{array}$} & \multicolumn{2}{|c|}{$\begin{array}{c}\text { Dairy system with crossing } \\
\text { with marketing strategy }\end{array}$} \\
\hline & & $\mathrm{TCDH}^{3}$ & $\mathrm{SCBH}^{4}$ \\
\hline Calving difficulty score, dir. ${ }^{5}$ & -5 & -17 & -17 \\
\hline Calving difficulty score, mat. ${ }^{6}$ & -2 & -15 & -16 \\
\hline 305-d milk yield & 100 & 100 & 100 \\
\hline Milk fat percentage & 27 & 35 & 35 \\
\hline Milk protein percentage & 38 & 49 & 49 \\
\hline SCS & -43 & -58 & -58 \\
\hline Clinical mastitis incidence & -8 & -10 & -10 \\
\hline Calf mortality at birth, dir. & -4 & -8 & -9 \\
\hline Calf mortality at birth, mat. & -3 & -48 & -67 \\
\hline Calf mortality during the rearing period, dir. & -8 & -10 & -11 \\
\hline Conception rate of heifers, dir. & 2 & 3 & 3 \\
\hline Conception rate of heifers, mat. & 2 & 2 & 3 \\
\hline Conception rate of cows, dir. & 18 & 27 & 28 \\
\hline Conception rate of cows, mat. & 15 & 165 & 167 \\
\hline Length of productive life of cows & 37 & 44 & 44 \\
\hline Birth weight, dir. & 0 & 0 & 0 \\
\hline Birth weight, mat. & 0 & -1 & -1 \\
\hline Mature weight of cows & -18 & -18 & -17 \\
\hline Daily gain in the rearing period, dir. & 18 & 20 & 20 \\
\hline Daily gain in fattening & 17 & 19 & 19 \\
\hline Dressing percentage & 20 & 23 & 23 \\
\hline Fleshiness & -4 & -4 & -4 \\
\hline Fat covering & 0 & 0 & 0 \\
\hline \multicolumn{4}{|l|}{${ }^{1}$ Calculated according to equation [4]. } \\
\hline \multicolumn{4}{|c|}{${ }^{2}$ These values were taken from the companion paper for scenario 2 (Wolfová et al., 2007). } \\
\hline \multicolumn{4}{|c|}{${ }^{3}$ Terminal crossing in dairy herds: all crossbred calves and dairy calves not needed for replacement are } \\
\hline \multirow{2}{*}{\multicolumn{4}{|c|}{$\begin{array}{l}\text { fattened. } \\
{ }^{4} \text { Selling crossbred breeding heifers: all male crossbred calves and dairy calves not needed for replacement } \\
\text { are fattened; female crossbred calves are sold to the integrated cow-calf pasture system. }\end{array}$}} \\
\hline & & & \\
\hline \multicolumn{4}{|l|}{${ }^{5}$ Direct component of the trait. } \\
\hline${ }^{6}$ Maternal component of the trait. & & & \\
\hline
\end{tabular}

\section{DISCUSSION}

\section{Evaluation of Dairy Bulls}

To the best of our knowledge, differences in the relative economic importance of traits for dairy sires used in purebred vs. beef $\times$ dairy crossbred production systems have not been reported. However, the Japanese beef industry puts great emphasis on the improvement of carcass traits. This, together with surplus milk production, motivates dairy farmers to cross a portion of their cows with beef bulls (Kahi and Hirooka, 2006). The expected liberalization of the milk market in the European Union will probably be accompanied by overproduction of milk and decreased milk prices. As shown by Wolfová et al. (2007), this could result in the reduced economic efficiency of dairy farms.

Terminal crossing has the potential to counteract such a decline in economic efficiency. In our companion paper (Wolfová et al., 2007), annual profitability in 2015 from a purebred dairy system in the Czech Republic was estimated to be $-5.5 \%$, in comparison with a profitability of $-3.8 \%$ for the dairy system with terminal crossing with Charolais bulls. Because governmental subsidies can be expected to be nearly the same for both production systems, the crossing of dairy cows with beef bulls is expected to enhance farm profitability and therefore be of increasing importance in the European Union. The relative importance of some traits of dairy sires used in the purebred system differs substantially from those of dairy sires used in a system using some crossbreeding with beef bulls. Therefore, a separate set of selection subindices for dairy sires that could be used in either system would be advantageous.

Under the production and economic circumstances modeled in our simulations, and with $11 \%$ of dairy cows mated to Charolais sires, the relative economic weights for dairy sires did not differ substantially between the 2 marketing systems (terminal crossing in dairy herds or production of $\mathrm{F}_{1}$ breeding females for a cow-calf beef production system). The same set of economic values for both crossing strategies is therefore recommended for the Czech Republic. With a different proportion of crossing or with higher emphasis on carcass quality, as described, for example, by Kahi and Hirooka (2006) 
Table 11. Relative standardized economic weights ${ }^{1}$ for Charolais sires used for crossbreeding in dairy production systems and in the cow-calf (backcrossing) system

\begin{tabular}{|c|c|c|c|}
\hline \multirow[b]{2}{*}{ Trait } & \multicolumn{2}{|c|}{$\begin{array}{l}\text { Dairy system with crossing } \\
\text { with marketing strategy }\end{array}$} & \multirow{2}{*}{$\begin{array}{l}\text { Cow-calf } \\
\text { system }\end{array}$} \\
\hline & $\mathrm{TCDH}^{2}$ & $\mathrm{SCBH}^{3}$ & \\
\hline Calving difficulty score, dir. ${ }^{4}$ & -100 & -100 & -100 \\
\hline Calving difficulty score, mat. ${ }^{5}$ & - & -31 & - \\
\hline Calf mortality at birth, dir. & -269 & -367 & -28 \\
\hline Calf mortality at birth, mat. & - & -223 & - \\
\hline Losses of calves in rearing or until weaning, dir. & -54 & -135 & -18 \\
\hline Losses of calves in rearing or until weaning, mat. & - & -190 & - \\
\hline Conception rate of heifers, dir. & - & 9 & 6 \\
\hline Conception rate of heifers, mat. & - & 20 & - \\
\hline Conception rate of cows, dir. & 920 & 634 & -5 \\
\hline Conception rate of cows, mat. & - & -17 & - \\
\hline Length of productive life of cows & - & 17 & - \\
\hline Birth weight, dir. & 8 & 4 & -4 \\
\hline Birth weight, mat. & - & -10 & - \\
\hline Mature weight of cows & 0 & 0 & - \\
\hline Daily gain during rearing or until weaning, dir. & 19 & 43 & -67 \\
\hline Daily gain during rearing or until weaning, mat. & - & -173 & - \\
\hline Daily gain in fattening & 124 & 140 & 61 \\
\hline Dressing percentage & 104 & 175 & 86 \\
\hline Fleshiness & -9 & -12 & -6 \\
\hline Fat covering & -5 & -8 & -4 \\
\hline
\end{tabular}

for Japanese conditions, greater differences between economic values for the 2 systems could occur. Using sexed semen for the production of dairy female replacements would substantially increase the portion of dairy cows available to produce crossbred progeny. However, the question is whether the increased costs for sexed semen could be covered by the increased revenues from the higher portion of animals with better carcass quality. The impact of this strategy on the economic efficiency of farms and on the economic value of traits for dairy sires should be investigated.

\section{Evaluation of Beef Bulls}

MacNeil et al. (1994), Phocas et al. (1998), Urioste et al. (1998), and Wolfová et al. (2005b) confirmed that production systems and marketing circumstances can have a major impact on the relative economic importance of traits in breeding objectives for beef cattle. Maternal trait components are of no importance when ranking beef bulls for terminal crossbreeding systems that do not use crossbred females for future breeding. However, if crossbred females are used for replacement, maternal trait components are important as well. Their importance relative to direct traits depends mainly on the proportion of crossbred females used for breeding and on their length of productive life.

The importance of traits or trait components for the evaluation of beef sires may differ according to whether the bulls are mated to dairy, beef $\times$ dairy crossbred, or beef cows. One reason for such a difference would be nonlinearities in the profit function, in which case different performance levels for the traits in the different cow populations would have a substantial impact on the ranking of beef bulls (Wilton et al., 2002). However, dependencies of sire ranking on the population of mates are not always found. Albera et al. (2004), for example, showed only a moderate dependence of the economic values of postweaning daily gain, live fleshiness score, calving difficulty score, and calving interval on trait levels in the population of dams. As demonstrated in the present investigation, differences in the incometo-cost ratios among animals of different genotypes in various production systems are a further reason for differences in the economic values for the same trait.

Amer et al. (2001) reported small differences in economic values for the direct effects of conception rate and calf mortality when mating beef bulls to beef cows or to dairy cows. This was not in agreement with our results, in which much higher differences were ob- 
served (see Tables 8 to 11). The reason was the differences in profit between the dairy and the cow-calf production systems. However, the economic value for calving ease in dairy cows estimated by Amer et al. (2001) was about 3 times the economic value for calving ease in beef cow herds, which was in good agreement with our results (Tables 8 and 9). The age distribution of a herd would affect the economic value of calving ease. Younger herds in a dairy system would freshen more heifers, with a higher percentage of calving problems.

On the basis of differences in the economic values observed for some traits, Amer et al. (2001) proposed using separate sets of economic values for calving ease and gestation length in separate subindices, depending on whether beef bulls are mated to dairy or beef cows. Kahi and Hirooka (2006) applied the same set of economic values to an evaluation of Japanese Black beef sires for purebreeding, terminal crossing with Holstein cows, and terminal crossing with Holstein $\times$ Japanese Black crossbred cows. They stated, however, that alternative breeding objectives and selection indices should be defined for the Japanese Black breeding program that would allow farmers to choose bulls that would ensure the highest genetic gain and profitability for their specific production system.

In Australia, the program Breed Object (Ponzoni et al., 1998) was developed to allow the construction of subindices for breeding bulls for different production circumstances in addition to a global selection index determined by the governing organization for each breed. For more specific farming systems, such as when bulls are purchased either as terminal sires to produce calves for export or for mating primarily to heifers or both, subindices could provide a relatively straightforward means of adjusting the selection emphasis accordingly.

On the basis of our results, we recommend that beef sires used for crossbreeding in dairy herds be evaluated by using indices with distinct economic values, according to whether crossbred daughters will be fattened for slaughter (terminal crossing) or sold to produce terminal backcross calves in cow-calf pasture production herds. Although there is no direct connection between breeders selecting and selling beef bulls and farmers buying the crossbred beef $\times$ dairy replacement females for their cow-calf pasture systems, an indirect connection exists through the dairy farmers who are interested in obtaining a maximum price for the crossbred heifers. Beef farmers would be willing to pay top price for heifers only if the heifers' sires have a high breeding value for production and functional traits. Therefore, both the owner of the dairy cows bred to the beef bulls and the buyer of the crossbred females would get the value of the beef bulls chosen for crossing.
The specific sets of economic values for dairy and beef sires for special farming systems calculated in this paper allowed for the construction of specific subindices for Holsteins and Charolais, the main breeds in the Czech Republic. The bioeconomic model described in the companion paper (Wolfová et al., 2007) and the appropriate computer program of Wolf et al. (2005) allowed for the calculation of appropriate sets of economic weights for additional breeds and different production systems.

\section{ACKNOWLEDGMENTS}

The authors would like to thank D. Bureš, L. Bartoň, R. Zahrádková, and J. Prribyl from the Institute of Animal Science Prague-Uhřiněves for their helpful comments, the Czech Beef Breeders Association, and the Holstein Cattle Breeders Association of the Czech Republic for making data available. Furthermore, the technical assistance of P. Mrázková is acknowledged. Special thanks are extended to W. D. Hohenboken (Corvallis, Oregon), who not only edited the English of the paper but also contributed helpful comments. The research project was supported by the Ministry of Agriculture of the Czech Republic (MZE0002701401).

\section{REFERENCES}

AFRC. 1993. Energy and Protein Requirements of Ruminants (advisory manual prepared by the AFRC Technical Committee on Responses to Nutrients), CAB International, Wallingford, UK.

Albera, A., P. Carnier, and A. F. Groen. 2004. Definition of a breeding goal for the Piemontese breed: Economic and biological values and their sensitivity to production circumstances. Livest. Prod. Sci. 89:67-78.

Amer, P. R., G. Simm, M. G. Keane, M. G. Diskin, and B. W. Wickham. 2001. Breeding objectives for beef cattle in Ireland. Livest. Prod. Sci. 67:223-239.

Berry, D. P., F. E. Madalena, A. R. Cromie, and P. R. Amer. 2006. Cumulative discounted expressions of dairy and beef traits in cattle production systems. Livest. Sci. 99:159-174.

Daňo, J., J. Huba, J. Kica, and L. Hetényi. 2001. Economic possibilities of breeding the suckling cow population in Slovakia. Agric. Econ. 47:247-254.

Davies, M. H., H. F. Grundy, and S. Page. 1992. Evaluation of Piemontese cross Friesian steers and heifers on silage-based diets. Anim. Prod. 54:500. (Abstr.)

Elsen, J. M., and J. C. Mocquot. 1974. Méthode de prévision de l'evolution du niveau génétique d'une population soumise à une opération de sélection et dont les génerations se chevauchent. INRA Bull. Tech. Dépt. Génét. Anim. 17:30-54.

Fox, D. G., C. J. Sniffen, J. D. O'Connor, J. B. Russell, and P. J. Van Soest. 1990. A model for predicting cattle requirements and feedstuff utilization. Pages 7-83 in The Cornell Net Carbohydrate and Protein System for Evaluation of Cattle Diets. Cornell Univ. Agr. Exp. Stn. No. 34. Cornell University, Ithaca, NY.

Güngör, M., A. Alçiçek, and A. Önenç. 2003. Feedlot performance and slaughter traits of Friesian, Piemontese $\times$ Friesian and Limousin $\times$ Friesian young bulls under intensive beef production system in Turkey. J. Appl. Anim. Res. 24:129-136.

Hill, W. G. 1974. Prediction and evaluation of response to selection with overlapping generations. Anim. Prod. 18:117-139. 
Kahi, K., and H. Hirooka. 2006. Economic efficiency of Japanese Black cattle selection schemes utilising crossbreeding with the Holstein breed. Anim. Sci. J. 77:178-187.

MacNeil, M. D., S. Newman, R. M. Enns, and J. Stewart-Smith. 1994 Relative economic values for Canadian beef production using specialized sire and dam lines. Can. J. Anim. Sci. 74:411-417.

Nielsen, H. M., A. Groen, J. Pedersen, and P. Berg. 2004. Stochastic simulation of economic values and their standard deviations for production and functional traits in dairy cattle under current and future Danish production circumstances. Acta Agric. Scand., Anim. Sci. 54:113-126.

Petrikovič, P., and A. Sommer. 2002. Potreba živín pre hovädzí dobytok. VÚŽV, Nitra, Slovak Republic.

Phocas, F., C. Bloch, P. Chapelle, F. Bécherel, G. Renand, and F. Ménissier. 1998. Developing a breeding objective for a French purebred beef cattle selection programme. Livest. Prod. Sci. 57:49-65.

Ponzoni, R. W., K. D. Atkins, S. A. Barwick, and S. Newman. 1998. Taking breeding objective theory to application: Experiences with the programs 'OBJECT' and 'BREEDOBJECT.' Vol. 25. Pages 375-378 in Proc. 6th World Congr. Genet. Appl. Livest. Prod. Organising Committee, 6th World Congress on Genetics Applied to Livestock Production, Armidale, Australia.

Roughsedge, T., P. R. Amer, and G. Simm. 2003. A bio-economic model for the evaluation of breeds and mating systems in beef production enterprises. Anim. Sci. 77:403-416.

Sommer, A., Z. Cerešňáková, Z. Frydrych, O. Králík, Z. Králíková, A. Krása, M. Pajtáš, P. Petrikovič, J. Pozdíšek, M. Šimek, J. Třináctý, B. Vencl, and L. Zeman. 1994. Potřeba živin a tabulky výživné hodnoty krmiv pro přežvýkavce. ČAZV, Pohořelice, Czech Republic.

Urioste, J. I., R. W. Ponzoni, M. A. Aguirrezabala, G. Rovere, and D. Saavedra. 1998. Breeding objectives for pasture-fed Uruguayan beef cattle. J. Anim. Breed. Genet. 115:357-373.

Vencl, B., Z. Frydrych, A. Krása, R. Pospíšil, J. Pozdíšek, A. Sommer, M. Sime, and L. Zeman. 1991. Nové systémy hodnocení krmiv pro skot. Akademie zemědělských věd CSFR. Praha, Czech Republic.

Wilton, J. W., C. J. B. Devitt, and S. P. Miller. 2002. Sensitivity of rankings of beef sires for non-linear multiple trait breeding objectives. In Proc. 7th World Congr. Genet. Appl. Livest. Prod. (CD-ROM). Communication no. 02-27. INRA-BP 27, Cedex, France.

Wolf, J., M. Wolfová, and E. Krupa. 2005. User's Manual for the Program ECOWEIGHT (C program for calculating economic weights in livestock), Version 2.0.18. Research Institute of Animal Production Prague-Uhříněves, Czech Republic, and Research Institute of Animal Production, Nitra, Slovak Republic.

Wolfová, M., and G. Nitter. 2004. Relative economic weights of maternal versus direct traits in breeding schemes. Livest. Prod. Sci. 88:117-127.

Wolfová, M., J. Wolf, J. Kvapilík, and J. Kica. 2007. Selection for profit in cattle. I. Economic weights for purebred dairy cattle in the Czech Republic. J. Dairy Sci. 90:2442-2455.

Wolfová, M., J. Wolf, J. Přibyl, R. Zahrádková, and J. Kica. 2005a Breeding objectives for beef cattle used in different production systems. 1. Model development. Livest. Prod. Sci. 95:201-215.

Wolfová, M., J. Wolf, R. Zahrádková, J. Přibyl, J. Daňo, E. Krupa, and J. Kica. 2005b. Breeding objectives for beef cattle used in different production systems. 2. Model application to production systems with the Charolais breed. Livest. Prod. Sci. 95:217-230. 